\title{
Aggression and Violence
}

Approaches to Effective Management 


\title{
AGGRESSION AND VIOLENCE
}

Approaches to Effective Management

\author{
Edited by \\ John Turnbull and Brodie Paterson
}

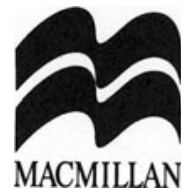


(C) Selection, editorial matter, Chapter 1: John Turnbull and Brodie Paterson 1999.

(C) Chapters 2, 3 and 10: John Turnbull; Chapter 4: Brodie Paterson and Cheryl Tringham; Chapter 5: Rob Wondrak; Chapters 6 and 7: Brodie Paterson and David Leadbetter; Chapter 8: Vaughan Bowie; Chapter 9: Colin Beacock, 1999.

All rights reserved. No reproduction, copy or transmission of this publication may be made without written permission.

No paragraph of this publication may be reproduced, copied or transmitted save with written permission or in accordance with the provisions of the Copyright, Designs and Patents Act 1988, or under the terms of any licence permitting limited copying issued by the Copyright Licensing Agency, 90 Tottenham Court Road, London W1P 9HE.

Any person who does any unauthorised act in relation to this publication may be liable to criminal prosecution and civil claims for damages.

The authors have asserted their right to be identified as the authors of this work in accordance with the Copyright, Designs and Patents Act 1988.

First published 1999 by

MACMILLAN PRESS LTD

Houndmills, Basingstoke, Hampshire RG21 6XS

and London

Companies and representatives throughout the world

ISBN 978-0-333-62251-3

ISBN 978-1-349-13577-6 (eBook)

DOI 10.1007/978-1-349-13577-6

A catalogue record for this book is available from the British Library.

This book is printed on paper suitable for recycling and made from fully managed and sustained forest sources.

$\begin{array}{llllllllll}10 & 9 & 8 & 7 & 6 & 5 & 4 & 3 & 2 & 1\end{array}$

$\begin{array}{llllllllll}08 & 07 & 06 & 05 & 04 & 03 & 02 & 01 & 00 & 99\end{array}$

Editing and origination by

Aardvark Editorial, Mendham, Suffolk 
To Rhîan, Beci and Rachel 


\section{CONTENTS}

Notes on Contributors

1. Introduction 1

John Turnbull and Brodie Paterson

2. Violence to Staff: Who is at Risk? $\quad 8$

John Turnbull

3. Theoretical Approaches to Violence and Aggression

John Turnbull

4. Legal and Ethical Issues in the Management of

Aggression and Violence

Brodie Paterson and Cheryl Tringham

Rob Wondrak

6. De-escalation in the Management of Aggression and Violence:

Towards Evidence-based practice

Brodie Paterson and David Leadbetter

7. Managing Physical Violence

Brodie Paterson and David Leadbetter

8. Providing Staff with Adequate Support: Health

Workers as Survivors of Assault and Aggression

Vaughan Bowie

9. A System of Education and Training for the Care and

Management of People with Special Needs who Display

Violent or Dangerous Behaviours

Colin Beacock

10. The Role of the Manager

John Turnbull

Index 


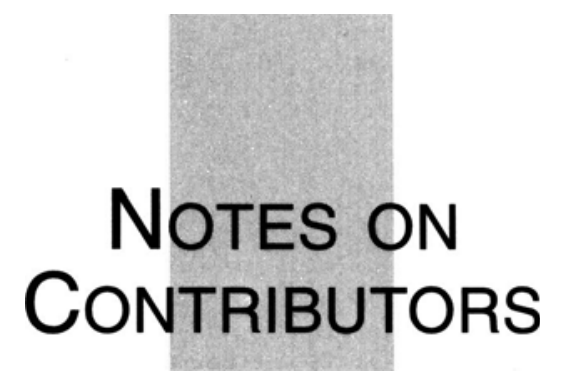

Colin Beacock MA, RNMH, RGN, CertEd was formerly Senior Education Officer at Rampton Hospital and is now a Professional Officer with the Royal College of Nursing. He is also co-editor (with Bob Gates) of Dimensions of Learning Disability, published in 1997.

Vaughan Bowie is a Lecturer in the Department of Social Policy and Human Services at the University of Western Sydney. He is the author of Coping with Violence: A Guide for Human Services and has been involved in the training of nurses and other health care workers in Australia, Canada, the United States and Northern Ireland.

David Leadbetter MSc, BA(Hons), CQSW, DSW, CSWE is an independent consultant trainer. He has published extensively on issues relating to aggression and violence at work, particularly in health care and social work settings.

Brodie Paterson MEd, BA(Hons), RMN, RNMH, RNT, DipNursing is a Lecturer in the Department of Nursing and Midwifery at the University of Stirling. An experienced trainer and practitioner, he has been involved for many years in research, publication and practice development in the field of managing aggression and violence.

Cheryl Tringham MPhil, RNT, RGN, RNMH is a Teaching Fellow in the Department of Nursing and Midwifery at the University of Stirling. She has a special interest in the professional, legal and ethical issues that arise within health care.

John Turnbull BA, MSc, RNMH is Director of Nursing at Oxfordshire Learning Disability NHS Trust. He has extensive experience as a practitioner, researcher and manager in the field of learning disability and has published widely on a range of topics. His previous post was that of Nursing Officer at the Department of Health.

Rob Wondrak MSc(PsychCouns), BA(Hons), CertEd, RMN, SRN, RNT is Head of Psychosocial Health, Oxford Brookes University, Isis Education Centre, Oxford. 